Articles

2006

\title{
Digital Campaigning: Using the Bill of Rights to Advance a Political Position
}

Kathy Swan

University of Kentucky

Mark J. Hofer

College of William and Mary

Follow this and additional works at: https://scholarworks.wm.edu/articles

Part of the Teacher Education and Professional Development Commons

\section{Recommended Citation}

Swan, Kathy and Hofer, Mark J., "Digital Campaigning: Using the Bill of Rights to Advance a Political Position" (2006). Articles. 42.

https://scholarworks.wm.edu/articles/42

This Article is brought to you for free and open access by W\&M ScholarWorks. It has been accepted for inclusion in Articles by an authorized administrator of W\&M ScholarWorks. For more information, please contact scholarworks@wm.edu. 


\section{Digital Campaigning: Using the Bill of Rights to Advance a Political Position}

\section{Kathy Swan \& Mark Hofer}

To cite this article: Kathy Swan \& Mark Hofer (2006) Digital Campaigning: Using the Bill of Rights to Advance a Political Position, The Social Studies, 97:5, 208-214, DOI: $10.3200 /$ TSSS.97.5.208-214

To link to this article: http://dx.doi.org/10.3200/TSSS.97.5.208-214

曲 Published online: 07 Aug 2010.

Submit your article to this journal \lceil

Џ Article views: 36

Q View related articles $๘$

Citing articles: 4 View citing articles 준 


\title{
Digital Campaigning: Using the Bill of Rights to Advance a Political Position
}

\author{
KATHY SWAN \\ MARK HOFER
}

$\mathbf{T}$ outed as the most expensive advertising campaigns in presidential history, final spending tallies for the 2004 presidential election came in at some $\$ 650$ million (OpenSecrets.org 2004). And this was just the total from the major political parties. Of particular interest was the impact of the so-called 527 committees, the political activist groups named after a section of the tax code that regulates them. Groups like the Swift Boat Veterans and POWs for Truth and MoveOn.org raised more than a half billion dollars during the 2003-2004 election cycle-double the amount spent during the previous year's cycle (Center for Public Integrity). While always thought to be on the fringes of the political process, some say that these groups played a decisive role in the outcome of the 2004 election. In the final three weeks of the campaign, the $527 \mathrm{~s}$ spent approximately $\$ 40$ million in last-minute commercials in key battleground states, with three quarters of the total spent on ads sup-

KATHY SWAN is an assistant professor of curriculum and instruction at the University of Kentucky in Lexington. MARK HOFER is an assistant professor of educational technology at the College of William and Mary in Williamsburg, Virginia. porting the Bush presidency (CNN News 2004).

Perhaps the most controversial advertisements were the ones were sponsored by the Swift Boat Veterans and POWs for Truth, an advocacy organization made up of former naval veterans of the Vietnam War and funded by opponents of Senator John Kerry's bid for the presidency. This cluster of commercials questioned Kerry's war record, specifically accusing him of lying to get his three Purple Hearts, Silver Star, and Bronze Star during his Vietnam service. These smear ads prompted an outcry from both left and right for the muckraking and caused Senator John McCain to cross party lines to try and end the slander. He remarked at a news conference in August 2004, "I think the ad is dishonest and dishonorable. As it is none of these individuals served on the boat [Kerry] commanded. Many of his crewmates have testified to his courage under fire. I think John Kerry served honorably in Vietnam" (Factcheck.org). MoveOn.org received similar criticism from conservatives, particularly centered on two commercials posted on the organization's Web site comparing President Bush to Adolf Hitler (Memory Hole). While these two ads represented only two out of a total 1,500 advertisements submitted to the site and were ultimately removed as they were voted down by the groups' membership, these indelible images, however short lived, were inflammatory to the democratic process and managed to make headlines (National Public Radio). Despite urging from both sides of the political arena, the ads continued and arguably amplified the chasm of an already bitterly divided nation.

\section{Digital Campaigning}

Teachers who want their students to explore the workings of the election process might have been remiss this year without addressing the rhetoric and false advertising claims made on both sides of the political spectrum. However, educating students to understand overt, subtle, and erroneous claims made by partisan advertisers is no small feat. Often students are passive consumers who need to learn how to become critical listeners, viewers, readers, and producers of all types of media (Considine and Haley 1999; Hyerle 1996; Messaris 1998). Because of this, media literacy - the ability to access, analyze, evaluate, and produce communication in a variety of forms-is growing in importance in schools across the country (Swaim 2002; Tryner 1998). 
This article documents one exercise in which preservice teachers at two universities assigned a project of creating digital advertisements as a mechanism for understanding the Bill of Rights and partisan politics. Specifically, using Windows Movie Maker, these preservice teachers crafted political commercials for the 2004 presidential election in which they advocated a position with regard to the First Amendment (freedom of speech) and the controversial Patriot Act, the Second Amendment (the right to bear arms) and the assault weapon ban, and the Fourth Amendment (freedom of religion) and reciting the pledge of allegiance in schools. The purpose of the project was for students to explore how media can be used (and abused) to advance a position using common persuasive techniques. Additionally, the students were asked to reflect on the "value-added" of the technology in the project and the power of digital media in our everyday lives.

\section{Teaching Muckraking}

Advocates of media literacy encourage instructional pedagogies that support students in the process of decoding, evaluating, analyzing, and producing both print and electronic media (Hobbs 1998). To this end, digital moviemaking can be a mechanism in which a variety of media (like images, sound, text, video, and narration) can be tapped to create short commercials by using user-friendly nonlinear video-editing software (such as Windows Movie Maker and Apple's iMovie). Students can quickly learn that media products have a point of view and often use persuasive techniques. Additionally, the near-ubiquitous access to the necessary software (Movie Maker and iMovie are bundled free with their respective operating systems) and hardware (including computers with Internet access and digital cameras), and the open-ended nature of digital movies present powerful opportunities for teachers to engage their students in their own versions of political muckraking. While the research base on student-generated video only recently emerged, it is becoming increasingly clear that stu- dents benefit from creating their own videos in different ways. The most common finding is that students are highly engaged in creating their videos-often far surpassing their typical levels of engagement (Kearney and Schuck 2003; Ryan 2002). Others contend that the authentic nature of the video production process both increases motivation (Burn et al. 2001; Hoffenberg and Handler 2001; Kearney and Schuck 2003) and provides unique opportunities to engage in discipline-specific processes, including scientific observation (Yerrick, Ross, and Molebash 2003). Digital video projects may also promote creativity (New 2006; Reid, Burn, and Parker 2002), and connect students with their out-of-school interests (Parker 2002). Researchers are just beginning to document the impact of digital video projects in the social studies classroom (Swan, Hofer, and Levstik, in press).

\section{Structuring the Digital Campaign}

This project was implemented over the course of three weeks in three classes, with a total of fifty students participating in the exercise. Students had access to a computer lab while in class and reported convenient access to technology at home as well. The students came into the project with basic computer skills (such as searching the Internet, word processing, and PowerPoint), but they had no experience with the creation of digital videos. Students at both universities were introduced to the project as a four-step process using an established organizing framework (Bull and Thompson 2004):

1. Analyzing media messages

2. Acquiring resources

3. Creating a position

4. Communicating their message

While each stage of the process is discussed in detail below with regard to this project, it is important to note that the steps within this pedagogical framework (see figure 1) can be rearranged to begin at any phase and can be useful in structuring other digital image projects (Berson and Swan 2005).
Analyze

Engaging students in becoming critical consumers is a thoughtful and deliberate process whereby students begin with the basic tenets of media literacy and then apply these skills in an authentic environment. In the study of media literacy, Hobbs (1997) establishes five basic concepts about media messages that form the foundation for developing skills, applications, and understanding: (1) All messages are constructions; (2) Messages are not representations of social reality; (3) Individuals negotiate meaning by interacting with messages; (4) Messages have economic, political, social, and aesthetic purposes; and (5) Each form of communication has unique characteristics. To acquaint students with the lenses with which to view a media message, they were introduced to the Livingroom Candidate Web site (American Museum of the Moving Image). This free online digital archive provides access to full-length versions of all of the campaign commercials in presidential elections from both major parties from 1952-2004. The collection includes written transcripts for each commercial and entry points to either browse the collection or search any number of commercials for key words. In small groups, students were asked to sift through the advertisements, select two commercials representing opposing viewpoints on either an issue or candidate, and answer the following questions (Public Broadcasting System):

Who is the target audience or demographic for the advertisement?

What is the ad trying to "sell" (a candidate, a political position, etc.) and for what purposes (economic, political, social, or aesthetic)?

What are the production elements or film techniques used to sell the message?

Students were then asked to think about their own perspectives, how they individually responded to the message, and what caused their response. An extended exercise is provided by the Center for Media Literacy (2005) and can be used to explore additional advertising and propaganda techniques. (See 


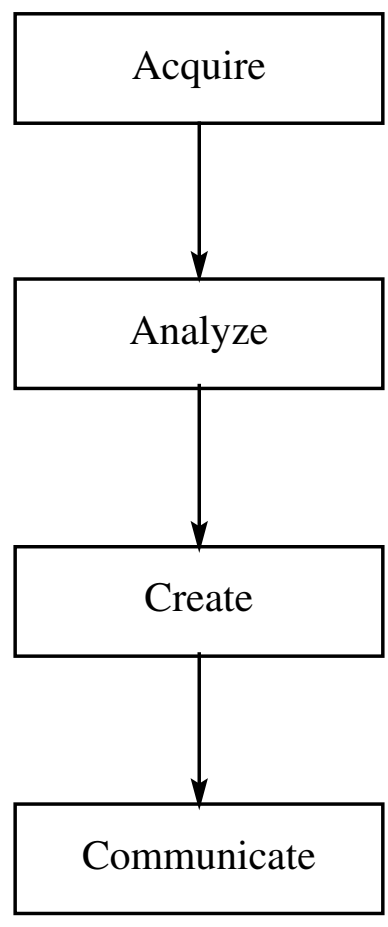

Students can access and select images and other media from digital cameras, scanners, and Web-based archives.

Once images have been collected, students must employ important analysis skills including categorization and classification and discussion of perspective embedded in each image to determine what will be useful in creating their PSAs.

Technology tools allow students to create a wide variety of projects with digital images including printed documents, digital stories, and digital documentaries.

With electronic projects including web pages and digital videos, students are able to communicate with a wider audience that includesparents and other students.

FIGURE 1. Framework for digital images.

Source. G. Bull and A. Thompson. 2004. Establishing a framework for digital images in the school curriculum. Learning and Leading with Technology 31 (8): 14-17.

appendix A for additional introductory resources to engage students in analyzing political propaganda.)

\section{Acquire}

With this context as a springboard, we challenged students to watch television closely (particularly political ads), scan the newspaper, and look online to identify issues in the election that relate to personal freedoms and the Bill of Rights. To facilitate the analysis process, students received a list of online resources, including the American Civil Liberties Union positions page (2005), CNN's election issues page (2004), and the National Archives' rich site for the Bill of Rights (2005). Upon completion of their research, students had to identify one issue tied to the Bill of Rights and take a position.

After identifying an issue and possible techniques to employ in their politi- cal public service announcement, the instructors tasked the students with collecting the "raw material" for their digital stories and discussed effective Internet search strategies to help them locate digital images and audio, music, and video clips from the Web to use in their commercials. Additionally, using an Internet evaluation site worksheet developed by Jim Burke, students judged the credibility of each site they visited in a concerted effort to authenticate their resources. The instructors also encouraged students to capture their own images and video clips using the schools' digital cameras and camcorders. Some students also created original artwork or scanned images from print sources.

In this phase, the instructors also discussed copyright and fair use laws and how they applied to using digital media for class projects. Fortunately, the U.S. Copyright Act takes into account the special needs and considerations of teachers and students, and has established The Fair Use Guidelines for Educational Multimedia, which provides certain guidelines under which teachers and students can legally use copyrighted materials in class projects. However, it is important to stress to students that just because something is posted on the Web does not mean it is free for others to use and that school projects are often exempted, as they are in a special context that the law recognizes (see appendix B).

\section{Create}

Once students identified an issue and position, created a game plan for using persuasive techniques, and acquired the necessary media and materials, they were introduced to the process of storyboarding their commercial. With the help of a word-processed template (Hofer 2005b), students created a storyboard of their commercial that laid out all the visual, audio, and action elements of the commercial. Students were shown how to copy appropriate images or visuals into the boxes and note the visual (transitions, captions) and audio elements for each shot. The instructors stressed the importance of sequencing the images and audio in an appropriate and effective way to convey the message. Because the suggested final run time was limited to roughly forty-five seconds, the content of the commercial had to be tightly focused on the core message. Upon completion of the storyboard drafts, students circulated their word-processed documents to multiple classmates to use Microsoft Word's electronic revision tools to provide comments on each other's work.

\section{Communicate}

Once the preproduction phases were complete, students were ready to create their public service announcements to communicate their message. After a brief demonstration of how to use the Movie Maker software, the instructors provided students with a Web-based tutorial (Digital Directors Guild) and 
gave class time to create the digital commercials. Aside from minor technical glitches, students had little trouble with this final phase of the process (in fact, many students identified the creation stage, rather, as the most challenging component of the project). Over the course of two seventy-five-minute class periods, most students were able to complete the public service announcements (Hofer 2005). A few groups had some technical difficulties that required them to work outside of class time, but many finished comfortably in the time allotted.

Among the projects were commercials that dealt with gun control, gay marriage, and Alaskan drilling. The creators of a gun control commercial launched the 57-second announcement with a thunderous gunshot followed by a series of stark black and white video vignettes depicting a number of dramatic scenarios, including a young child inadvertently shooting a firearm and unintentionally killing another child. While simple in its approach, the directors chose not to include narration and instead opted for classical music as a backdrop for snapshots of the military and the array of firearms available on the open market. The commercial ended with a quote that read

The people made the Constitution and the people can unmake it. It is the creature of their will and lives only by their will.

—Chief Justice John Marshall, 1821

The final seconds of the commercial conveyed the directors' definitive message: "Support Gun Control Legislation."

\section{Reflecting on the Experience}

After the students completed their projects, they had the opportunity to see each other's work and discuss the use and power of digital media to advocate a position, an important benefit resulting from student-generated video projects (Kearney and Schuck 2003). Following this discussion, instructors asked students to complete a written reflection of the opportunities and challenges of this assignment and how a similar project might be implemented in their future schooling. Students' written reflections identified several advantages and disadvantages to this type of exercise. Specifically, students were concerned with the amount of class time spent on the project, technical difficulties, and access to the necessary technology in $\mathrm{K}-12$ schools.

Many of the students were concerned about the time spent on the projectnoting the pressure teachers feel to cover the required content. This is clearly an important concern that should be addressed. From start to completion, five class periods (seventy-five minutes each) were allotted for production of the videos, with another half period to screen the finished products. This included time for the background research, collecting images and sound clips, writing, revising, and the actual production of the video. While some of this could have been done outside of class as an assignment, at least two days would be necessary in the computer lab to actually put the movies together. With this said, one student reported, "I think the benefits outweigh the costs. Yeah, it took time away from other activities, but with this project it would be possible to cover all kinds of content in just one project."

Students also expressed concerns related to technical difficulties or limitations of the software used. While only two students reported major challenges in using the Movie Maker software, several noted minor problems in completing their projects. Most of the problems occurred when students began the project on one computer and continued on a different computer, causing some problems in accessing all the needed project files. More students reported frustration with limitations of the software. Several wished to incorporate both recorded narration and music simultaneously in their movies. And while a way to work around it was discovered by one of the students, most were not able to accomplish this in their final products. One student reflected, "For what we were doing, I think the software was pretty simple. There were some things that I wanted to do but either didn't know how to do, or the software wasn't able to do. That was a little frustrating but it made me be more creative and find other ways to convey my message." One student effectively summed up the collective view regarding the technical challenges of the product: "While I had many technical issues, none of them were to the point where I could not overcome them."

Finally, many students expressed concern about access to the necessary technology to implement this type of project in a typical $\mathrm{K}-12$ classroom. It is certainly true that the typical teacher education program at a college or university is probably better equipped than the typical $\mathrm{K}-12$ school. This criticism is particularly true when it comes to student-to-computer ratio and access to advanced hardware and software. The technology used in this project, however, was completed using Windows Movie Maker, included as a part of the Windows XP operating system. Many schools may have computers with older operating systems, but as equipment is upgraded, this gap in access is minimized.

In summary, students acknowledged the costs of doing this kind of project, but nearly all reported that the benefits outweighed the costs. Students cited the opportunity for student creativity and pride in their accomplishment, the process which linked multiple content topics and skills, and student engagement with content as advantages to this type of assignment.

Most often students referenced the creative element of producing their own commercials as a significant advantage. One student noted that "the end result is really cool, students can really get their message across in so many different ways, and it is different than any other project that can be done." Other students recognized this type of project as a creative alternative to traditional research reports. Many felt a sense of pride with their projects. One student's comment appreciated "the opportunity to create something professional ... I know I'm proud of mine."

The reflections also revealed an appreciation for the four-step process employed in the activity, noting the con- 
fluence of content, skills, and creativity. One student stated, "It was a great project because you had to do so many small tasks, such as research and importing narration, but they all tied together in the end so the final result was a great reward." Another emphasized the student-directed nature of the project, remarking, “. . . Students take on the responsibility not only for their learning but also how the finished digital story comes out. They become invested in the process and learning about the topic and technology. Which are both vital parts of their digital stories."

Finally, the students appreciated the engagement with the content that this project engendered, noting that the project might promote interest in topics that students might otherwise find boring. Specifically, one student observed that the project "teaches the impact technology can have on people (in the form of persuasion)." A typical problem with integrating technology in an activity is that some students focus more on style over substance. In this case, however, some students felt differently. One student stated, "I was surprised how easy the software was to use. A lot of projects using new technology end up focusing more on how to use and operate the medium, but here it was very easy and quick to learn the software resulting in more focus on the content of the video." Finally, and perhaps most importantly, another remarked, "I think it made all of us look at the election and politics a little more closely."

\section{A Cautionary Note When Teaching Controversial Issues}

One thing to consider prior to implementing this project, or any project that focuses on controversial issues in the classroom, is that some students, parents, or both may hold beliefs and values that may be questioned or challenged by the teacher or students. In this case, it is important to notify parents of the purpose, intent, and scope of the project prior to beginning work, offering parents who may have concerns the opportunity to discuss issues prior to implementation and allowing for other assignments or accommodations. In the classroom, it is essential to discuss with the students that different people have different views on issues and that it is important to respect the views of others and limit challenges or criticism to a civil discussion. It is very important to immediately deal with any improper student conduct to defuse brewing conflicts. While certainly a challenge for the teacher, openly discussing different views and respecting others' perspectives is an important part of the social studies classroom.

\section{Access to Technology}

While this type of project is most efficiently completed in a computer lab with one-to-one access to the necessary technology, there are other approaches to completing the project in the classroom with fewer computers available. In the Acquire, Analyze, and Create stages, there may actually be some advantages to cycling students through one or two classroom computers to do background research while the rest of the class focuses on persuasion and propaganda techniques. In this approach, students may be more able to focus on the core content of the project as they devise their commercials rather than spending an inordinate amount of time on surfing the Web. Also, teachers may choose to lead a discussion on several sample commercials using the instructor's computer hooked to an LCD projector or TV scan converter. In this way, the students can analyze techniques and approaches in a more efficient way.

In the Communicate stage, limited access to technology may be more challenging. In a one- or two-computer classroom, it is essential that students are efficient with their time on the computer so that all students are able to cycle through the station(s). The authors suggest requiring students to provide a completed (and revised) storyboard and collection of resources before taking their turn on the computer. With this preproduction work completed, students should be able to complete the commercial itself in as little as thirty minutes' time. One other suggested approach would be to ensure that students focus on building the core of their commercials before spending time on transitions, effects, and other nonessential elements of the video. In this way, they will be sure to focus on the key elements emphasized in class and limit their work with stylistic elements in remaining time.

\section{Conclusion}

Students today live in an increasingly media-saturated world. And while they are frequent consumers of television and Web-based media (Pewinternet 2003), it is unclear how effective they are at decoding and analyzing the material with which they are confronted (Considine and Haley 1999; Messaris 1998). Recent events like the 2004 presidential election and media coverage of other important issues around the world provide a timely and relevant opportunity to engage students in discussions of media literacy. Paired with user-friendly digital video-editing software like Windows Movie Maker, students can explore issues of persuasion and point of view as both consumers and producers of the media (Hobbs 1998). Yet while there is potential in this approach, both the modeling of technology integration in teacher education programs and the pedagogical challenges encountered in undertaking this kind of work merit further exploration and analysis.

The implementation of technology projects with preservice teachers is beneficial for several reasons. It provides students with exemplary models of technology integration that, by their very nature, imply a student-centered approach in addition to a strong pedagogical or theoretical rationale. Additionally, experimenting with technology helps educators develop intuitions about the implementation process, the challenges with the technology, and other logistical issues. However, without trying digital moviemaking projects in $\mathrm{K}-12$ classrooms using empirical methods of research, it is difficult to advocate its wider use in education until we begin to more formally assess the tool's impact on student learning. As a mechanism for 
building a community of scholars and practitioners to help chart the course of digital moviemaking in the social studies, the Digital Directors Guild (http:// www.ddguild.org) has been developed to provide a space in which $\mathrm{K}-16$ educators can explore digital moviemaking, its place in the curriculum, and its impact on student learning.

Housed within the site is an expanding matrix of student-created digital movies, including examples across all grade levels and content areas. In social studies, scholars are beginning to experiment with digital moviemaking in specific disciplines such as history, geography, and economics. Along with profiles of educators who have employed digital movies in the classroom, an extensive collection of pedagogical and technical resources is also incorporated to assist teachers in the implementation process. A Frequently Asked Questions section has also been developed with a discussion board providing opportunities for educators to share ideas, resources, tips, and tricks. Ultimately, the intention of the site is to provide a forum in which educators can become collaborators on an evolving, shared research agenda that measures the impact of digital moviemaking projects on student learning. We invite readers of The Social Studies to join us in investigating digital moviemaking across the whole range of social studies.

Key words: Bill of Rights, digital campaigning, muckraking, public service announcement

\section{APPENDIX A}

\section{USEFUL WEB RESOURCES}

The Living Room Candidate from the American Museum of the Moving Image (http://livingroomcandidate.movingimage.us /index/php) provides digitized versions of all television commercials that aired for presidential candidates in every election since 1952, including written transcripts and the ability to search commercials by key words.

Motion Picture Analysis Worksheet from NARA (http://www.archives.gov/digital_ classroom/lessons/analysis_worksheets/ movie.html), Analyzing Propaganda in Print Ads and Commercials from Read
Write Think (http://www.readwritethink.org/ lesson_images/lesson405/Analyzing PropagandainPrintAds.pdf), and Propaganda Techniques Used in Online Political Ads from Read Write Think (http://www.read writethink.org/lesson_images/lesson405/ PropagandaUsedOnline.pdf) are all useful resources to help students analyze point of view and techniques used to sell a message.

Propaganda Critic (http://www.propa gandacritic.com) explores common propaganda techniques (and corresponding examples) used to advance a position.

Dissect an Ad from PBS (http://www.pbs .org/pov/pov1996/takingonthekennedys/dis sect.html) is an exercise developed by the Center for Media Literacy, which challenges visitors to critically analyze campaign commercials.

Jib Jab (http://www.jibjab.com/index .asp) and True Majority Action (http:// www.truemajority.org/oreo) offer engaging animations that satire politicians and current issues up for debate.

\section{APPENDIX B}

\section{COPYRIGHT INFORMATION}

One issue of concern in implementing this type of project is ensuring that copyright and fair use of materials posted on the Web is honored. Contrary to what many believe, material posted on the Web is still often considered intellectual property and covered by copyright laws. Fortunately for teachers, the U.S. Copyright Act considers the special needs and considerations of teachers and students. The Fair Use Guidelines for Educational Multimedia provides certain guidelines under which teachers and students can legally use copyrighted materials in class projects. Before making student work using copyrighted materials (particularly posting projects on the Web), it would be wise for a teacher to explore copyright issues in more depth (http://www.copyright.gov and http:// www.thecopyrightsite.org/index.html will be helpful resources to begin).

\section{REFERENCES}

American Civil Liberties Union. 2005. http://www.aclu.org (accessed January 10, 2005).

American Museum of the Moving Image. 2005. The Living Room Candidate, http://livingroomcandidate.movingimage .us/index.php (accessed January 10, 2005).

Berson, M., and K. O. Swan. 2005. Digital images in the social studies classroom. In Digital images in the school curriculum, ed. G. Bull and L. Bell. Eugene, OR: International Society for Technology in Education.

Bull, G., and A. Thompson. 2004. Establishing a framework for digital images in the school curriculum. Learning and Leading with Technology 31 (8): 14-17.

Burke, J. 2001. Illuminating texts: How to teach students to read the world. Portsmouth, NH: Heinemann.

Burn, A., S. Brindley, J. Durran, C. Kelsall, J. Sweetlove, and C. Tuohey. 2001. The rush of images: A research report into digital editing and the moving image. English in Education 35 (2): 34-47.

The Center for Media Literacy. 2005. How to analyze an advertisement. http://www .medialit.org/reading_room/article227.html (accessed January 10, 2005).

The Center for Public Integrity. 2004. 527s in 2004 shatter previous records for political fundraising. http://www.publicintegrity .org $/ 527 /$ report.aspx $?$ aid $=435 \&$ sid $=300$ (accessed January 10, 2005).

CNN News. 2004. America Votes 2004: Campaign Ads. http://www.cnn.com/ ELECTION/2004/special/president/ campaign.ads/ (accessed January 10, 2005).

CNN News. 2004. CNN's election issues page. http://www.cnn.com/ELECTION/ 2004/special/president/issues/ (accessed January 10, 2005).

Considine, D. M., and G. E. Haley. 1999. Visual messages: Integrating imagery into instruction, 2nd ed. Englewood, CO: Teacher Ideas Press.

The Digital Directors Guild. 2005. Moviemaker tutorial. http://www.ddguild .org/materials/moviemaker_tutorial.doc (accessed January 10, 2005).

Factcheck.org. Republican-funded group attacks Kerry's war record. http://www .factcheck.org/article231.html (accessed January 10, 2005).

Hobbs, R. 1997. Literacy for the information age. In Handbook of research on teaching literacy through the communicative and visual arts, ed. J. Flood, S. Heath, and D. Lapp. New York: Simon and Schuster Macmillan.

. 1998. The seven great debates in the media literacy movement. Journal of Communication 48:16.

Hoffenberg, H., and M. Handler. 2001. Digital video goes to school. Learning and Leading with Technology 29 (2): 10-15.

Hofer, M. 2005a. Digital story project. http:// pages.towson.edu/mhofer/istc301/materials/ assignments/digital_story_project.html (accessed January 10, 2005).

- . 2005b. Storyboard template. http://pages.towson.edu/mhofer/istc301/ materials/storyboard_template.rtf (accessed January 10, 2005).

Hyerle, D. 1996. Visual tools for constructing knowledge. Alexandria, VA: Associa- 
tion for Supervision and Curriculum Development.

Kearney, M., and S. Schuck. 2003. Authentic learning through the use of digital video. In W. Au and B. White (eds.) Proceedings of the Australian Computers in Education Conference. (CD-ROM).

The Memory Hole. 2005. The Bush-Hitler ads removed by MoveOn. January 1 . http://www.thememoryhole.org/pol/bushhitler-ads.htm (accessed January 14, 2005).

Messaris, P. 1998. Visual aspects of media literacy. Journal of Communication 48 (1): 70-80.

National Archives Experience. 2005. Charters of freedom. http://www.archives.gov/ national_archives_experience/charters/bill_ of_rights.html (accessed January 10, 2005).

National Public Radio. 2004. Using Hitler to make a political point. http://www.npr.org/ templates/story/story.php?stryId=3111005 (accessed February 4, 2004).

New, J. 2006. Film school: The silver screen inspires young minds to think big. Edutopia 1 (9): 20-23.

OpenSecrets.org. 2004. 2004 presidential election. http://www.opensecrets.org/ presidential/index.asp?sort $=\mathrm{E}$ (accessed January 14, 2004).

Parker, D. 2002. Show us a story: An overview of recent research and resource development work at the British Film Institute. English in Education 36 (1): 38-44.

Pewinternet.org. 2003. Pew Internet and American life project: Teenage life online. http://www.pewinternet.org (accessed February 4,2004$)$.

Public Broadcasting System. 2004. Taking on the Kennedys. http://www.pbs.org/pov/ pov1996/takingonthekennedys/dissect.html (accessed January 10, 2005).
Reid, M., A. Burn, and D. Parker. 2002. Evaluation report of the Becta digital video pilot project. Coventry: Becta.

Ryan, S. 2002. Digital video: Using technology to improve learner motivation. Modern English Teacher 11 (2): 72-75.

Swaim, S. 2002. Media literacy for middle level students: An important curriculum component. Telemedium, the Journal of Media Literacy 48 (6): 6.

Swan, K. O., M. Hofer, and L. Levstik. Forthcoming. And action: Students collaborate in the Digital Directors Guild. Social Studies and the Young Learner.

Tryner, K. 1998. Literacy in a digital world: Teaching and learning in the age of information. Mahwah, NJ: Lawrence Erlbaum.

Yerrick, R., D. Ross, and P. Molebash. 2003. Promoting equity with digital video. Learning and Leading with Technology 31 (4): 16-19. 